\title{
Genetic effects of rooting loblolly pine stem cuttings from a partial diallel mating design ${ }^{1}$
}

\author{
Brian S. Baltunis, Dudley A. Huber, Timothy L. White, Barry Goldfarb, and \\ Henry E. Stelzer
}

\begin{abstract}
More than 239000 stem cuttings from nearly 2200 clones of loblolly pine (Pinus taeda L.) were set in five rooting trials to estimate genetic parameters associated with rooting. Overall rooting success across the five trials was $43 \%$, and significant seasonal effects were observed. Differences among clones within full-sib families accounted for approximately $10 \%-17 \%$ of the total variation. On the binary scale, individual-tree narrow-sense heritability $\left(\hat{h}_{0,1}^{2}\right)$ ranged from 0.075 to 0.089 for rooting across the five separate settings, while broad-sense heritability $\left(\hat{H}_{0,1}^{2}\right)$ ranged from 0.15 to 0.22 . Narrow- and broad-sense heritability estimates on the observed binary scale were transformed to their underlying normal scale $\left(\hat{h}_{\mathrm{N}}^{2}, \hat{H}_{\mathrm{N}}^{2}\right)$. When all of the data from the five trials were analyzed together, $\hat{h}_{\mathrm{N}}^{2}( \pm \mathrm{SE})$ was $0.081(0.027), \hat{H}_{\mathrm{N}}^{2}$ was $0.16(0.013)$, the type B additive correlation was $0.68(0.23)$, and the type B dominance correlation was $0.61(0.27)$. Narrow-sense family mean heritability was $0.83(0.24)$, while broad-sense clonal mean heritability was 0.82 (0.074). These moderate to high family and clonal mean heritabilities, moderate type B correlations, and substantial among-family and among-clone genetic variation indicate the potential for increasing rooting efficiency by selecting good rooting families and clones or culling poor rooters.
\end{abstract}

Résumé : Les auteurs ont estimé les paramètres génétiques associés à l'enracinement des boutures à l'aide de 239000 boutures représentatives de presque 2200 clones de pin à encens (Pinus taeda L.) et qui ont été réparties dans cinq tests d'enracinement. Le taux global d'enracinement dans les cinq tests était de $43 \%$ et des effets saisonniers significatifs ont été observés. Les différences entre les clones au sein des descendances biparentales représentaient approximativement 10 à $17 \%$ de la variation totale. À l'échelle binaire, l'héritabilité individuelle au sens strict $\left(\hat{h}_{0,1}^{2}\right)$ pour l'enracinement variait de 0,075 à 0,089 parmi les cinq tests, alors que l'héritabilité au sens large $\left(\hat{H}_{0,1}^{2}\right)$ variait de 0,15 à 0,22 . Les estimations d'héritabilité au sens strict et au sens large à l'échelle binaire utilisée ont été transformées selon la distribution normale sous-jacente $\left(\hat{h}_{\mathrm{N}}^{2}, \hat{H}_{\mathrm{N}}^{2}\right)$. En analysant simultanément l'ensemble des données des cinq tests, $\hat{h}_{\mathrm{N}}^{2}$ et $\hat{H}_{\mathrm{N}}^{2}$ affichaient des valeurs ( \pm erreur-type) respectives de $0,081(0,027)$ et de $0,16(0,13)$. Quant à elles, les corrélations additive de type $\mathrm{B}$ et de dominance affichaient des valeurs respectives de $0,68(0,23)$ et de $0,61(0,27)$.

L'héritabilité familiale moyenne au sens strict était de $0,83(0,24)$ alors que l'héritabilité clonale moyenne était de 0,82 $(0,074)$. Ces valeurs modérées à élevées d'héritabilité moyenne familiale et clonale, les valeurs modérées de corrélation de type $\mathrm{B}$ de même que la variation génétique substantielle remarquée parmi les descendances et les clones indiquent qu'il est possible d'augmenter l'efficacité d'enracinement en sélectionnant les descendances et les clones qui montrent une bonne aptitude à l'enracinement, ou en éliminant les pires sujets à ce chapitre.

[Traduit par la Rédaction]

\section{Introduction}

Loblolly pine (Pinus taeda L.) is the most important commercial tree species in the southern United States with over 1.1 billion seedlings planted annually (McKeand et al. 2003). There are three cooperative tree improvement programs in the southern United States that focus on improvement of southern pine species including loblolly pine: the Cooperative Forest Genetics Research Program, the North Carolina
State University - Industry Cooperative Tree Improvement Program, and the Western Gulf Forest Tree Improvement Program. Loblolly pine tree improvement programs in the southern United States are beginning their third generation of breeding, with gains in volume per unit area up to $30 \%$ over unimproved loblolly pine (McKeand et al. 2003).

Long-term tree improvement programs aim to increase the population mean breeding value of a few key traits through breeding and selection of superior genotypes. These pro-

Received 6 August 2004. Accepted 20 January 2005. Published on the NRC Research Press Web site at http://cjfr.nrc.ca on 31 May 2005.

B.S. Baltunis, ${ }^{2}$ D.A. Huber, and T.L. White. School of Forest Resources and Conservation, Institute of Food and Agricultural Sciences, University of Florida, Gainesville, FL 32611, USA.

B. Goldfarb. Department of Forestry, North Carolina State University, Raleigh, NC 27695, USA.

H.E. Stelzer. Department of Forestry, University of Missouri - Columbia, Columbia, MO 65211, USA.

${ }^{1}$ Journal Series No. R-10868 of the Florida Agricultural Experiment Station, Gainesville, Florida.

${ }^{2}$ Corresponding author (e-mail: baltunis@ufl.edu). 
Table 1. Experimental design for five rooting trials of loblolly pine stem cuttings.

\begin{tabular}{lllllll}
\hline Trial & Date set & $\begin{array}{l}\text { No. of } \\
\text { families }\end{array}$ & $\begin{array}{l}\text { No. of } \\
\text { clones }\end{array}$ & $\begin{array}{l}\text { No. of plots } \\
\text { per clone }\end{array}$ & $\begin{array}{l}\text { No. of cuttings } \\
\text { per plot }\end{array}$ & $\begin{array}{l}\text { Total } \\
\text { cuttings }\end{array}$ \\
\hline Spring01 & 7-11 May 2001 & 70 & 2194 & 4 & 4 & 34707 \\
Summer01 & 2-6 July 2001 & 70 & 2157 & 5 & 4 & 43048 \\
Winter02 & 14-18 Jan. 2002 & 61 & 1648 & 6 & 5 & 49315 \\
Spring02 & 29 Apr. - 3 May 2002 & 61 & 1254 & 6 & 9 & 67059 \\
Summer02 & 24-28 June 2002 & 61 & 947 & 6 & 9 & 45108 \\
\hline
\end{tabular}

Note: All trials were established in randomized complete block designs with four to six blocks and four to nine ramets per clone in a row plot within each block.

grams are based on recurrent selection for general combining ability that captures only the additive portion of the genetic variance. In any given generation of breeding, maximum gains can be achieved in the deployment population by capturing all of the genetic variation (additive and nonadditive components) through operational propagation of selected clones. With elite genotypes becoming available, several forest industries in the southeastern United States are developing rooted cutting programs for loblolly pine for the deployment of tested clones or families (Weber and Stelzer 2000).

Clonal tests derived from full-sib families provide an opportunity to estimate additive and nonadditive genetic components of variance associated with a particular trait or set of traits (Isik et al. 2003, 2004). In clonal field trials, traits of interest may include height, volume, wood quality, and disease resistance. However, to establish clonal field trials the clones must first be propagated. Therefore, clonal rooting trials are important for estimating genetic variance components associated with rooting.

Previous studies of loblolly pine rooting have been relatively small in size, ranging from several hundred (Goldfarb et al. 1998; Foster et al. 2000) to several thousand cuttings (Foster 1990; Anderson et al. 1999). Many studies contained a small number of families from factorial mating designs (Goldfarb et al. 1998; Anderson et al. 1999; Cooney and Goldfarb 1999; Frampton et al. 1999), and few studies have been designed to estimate genetic parameters associated with rooting in loblolly pine (Foster 1978, 1990; Anderson et al. 1999). The current study is unique in that a large number of cuttings were set in each trial (> 34000$)$, and rooting was assessed on nearly 2200 clones of loblolly pine from 70 fullsib families derived from a partial diallel mating design to estimate genetic parameters associated with rooting. The objectives of the study were to $(i)$ evaluate the rooting ability of stem cuttings from nearly 2200 loblolly pine clones, (ii) determine the causal components of variance in rooting of stem cuttings, (iii) assess heritability estimates for rooting from five trials both on the observed binary scale and on the underlying normal scale, and (iv) determine the type B genetic correlations for both additive and dominance genetic effects to measure the correspondence in rooting performance across five setting dates.

\section{Materials and methods}

\section{Population}

The parental population for this study was selected from the Loblolly Pine Lower Gulf Elite Population, which consists of selections from all three southern pine tree improvement cooperatives: the Cooperative Forest Genetics Research Program, the North Carolina State University - Industry Cooperative Tree Improvement Program, and the Western Gulf Forest Tree Improvement Program. Twenty first-generation and 10 second-generation selections representing both Atlantic Coastal Plain and Florida provenances were selected from this population. Two additional slow-growing parents were included to provide linkage with another study. These parents were crossed in a circular diallel mating design (FBRC 2000) with some additional off-diagonal crosses, resulting in a total of 70 full-sib families. On average, each parent was involved in approximately four crosses.

Seeds from the 70 families were sown in March 2000 into Ray Leach SuperCells (Stuewe and Sons, Corvallis, Oregon). The seedlings were grown in a greenhouse at International Paper Company's facility in Jay, Florida, and after 3 months of growth the seedlings were pruned back to a height of about 10-12 cm. Approximately 32 seedling hedges (ortets) per full-sib family were transplanted into 3-gallon ( 1 gallon $=3.785 \mathrm{~L})$ containers and given unique clonal identifications in September 2000. The hedges were repeatedly sheared to minimize the effects of maturation and increase the number of shoots available for the rooting trials. The ortets were randomized in a containerized hedge orchard to reduce spurious $\mathrm{C}$ effects at the family level. However, $\mathrm{C}$ effects at the clonal level could not be accounted for, because all cuttings originated from a single seedling ortet.

\section{Experimental design}

Two rooting trials were conducted in 2001 and three were conducted in 2002. Stem cuttings between 3 and $8 \mathrm{~cm}$ in length were harvested from the seedling ortets in May 2001, July 2001, January 2002, April-May 2002, and June 2002, for trials spring01, summer01, winter02, spring02, and summer02, respectively. Cutting size was relatively consistent within any trial, and the cuttings set in winter02 were the smallest. The experimental design differed among the trials because the number of families, clones, and available cuttings varied among ortets (Table 1). The reduction in the number of families and clones between the first and last rooting trials was a result of a number of factors. First, random hedge mortality was a major factor - disease, repeated severe pruning, and uneven watering (inadequate) all contributed to the random loss of hedges. Since cuttings of a clone originated from a single ortet, mortality resulted, by default, in a truncated population for future rooting trials. Second, not all hedges produced an adequate number of cut- 
tings at every harvest. The primary objective of the three settings in 2002 was to produce propagules for field trials. Therefore, clones that were not producing enough shoots to ultimately be planted across six field sites were culled regardless of rooting frequency. This resulted in the reduction in the number of families in the last three rooting trials because there were too few surviving clones in some of the families to meet the goal for field designs. We were striving for a balanced field design with 15 clones from each of 61 full-sib families.

Cuttings were randomly set in four-, five-, or nine-cutting clonal row plots (Table 1) into preformed plugs consisting of peat moss, perlite, and a binding resin. Each plug was approximately $13 \mathrm{~mL}$ in volume and was held by the V-13 HIKO tray (Stuewe and Sons, Corvalis, Oregon). Cuttings were either treated prior to setting with a $1.0 \%$ indole-3-butyric acid and $0.5 \%$ napthalene-1-acetic acid basal dip or after setting using a foliar napthalene-1-acetic acid application according to International Paper Company's protocols. Trays contained 15 to 30 clones depending on the trial and were randomly placed in an environmentally controlled greenhouse. There were four to six complete replications depending on trial (Table 1).

Rooting assessments were made 9 weeks after setting for both the spring01 and summer01 trials. Cuttings were measured for presence (1) or absence (0) of roots. Cuttings with a root $\geq 1 \mathrm{~mm}$ were considered rooted (Goldfarb et al. 1998; Foster et al. 2000). For trials winter02, spring02, and summer02 assessments were done 11 weeks after setting. Cuttings in these trials were also scored for presence or absence of roots. However, only cuttings that had at least one visible root on the exterior of the plug, regardless of length, were considered rooted.

\section{Statistical analyses}

For binomial traits, such as rooting, the unit of analysis can be the individual observations (Huber et al. 1994; Dieters et al. 1996) or the plot means combined with a transformation such as arcsin or logistic (Sohn and Goddard 1979; De Souza et al. 1991). We chose to analyze the observed 0,1 data for several reasons. First, restricted maximum likelihood (REML) estimation of variance components has been shown to be robust to violations of the underlying normality assumptions (Banks et al. 1985; Westfall 1987), suggesting that analyses using individual observations of binary data yield satisfactory results. Second, simulation studies have shown that the use of individual observations is superior to the use of plot means in REML and that these variance component estimates perform well across mating designs and imbalanced data (Huber et al. 1994). Huber et al. (1994) showed that a lower variance among estimates was obtained with individual observations than with plot means and that this advantage increased with increasing imbalance. Third, when heritability is low and the incidence close to $50 \%$, there is little difference between heritability estimates on the binary and transformed scale (Dempster and Lerner 1950). In fact, these two estimates are equivalent when the incidence is exactly $50 \%$ for low-heritability traits. Lopes et al. (2000) demonstrated that the Dempster and Lerner (1950) threshold model closely estimates the true underlying heritability at incidences between $25 \%$ and $75 \%$ for traits with low heritability $\left(h^{2} \leq 0.3\right)$. Finally, Lopes et al. (2000) also demonstrated (for traits with low heritability) that heritability estimates from the observed binary data without transformation of data result in predicted gain close to the realized gain, while transformations can be affected by problems associated with back transformation when you wish to predict gains on the original scale.

For each of the five rooting trials, all variance components for rooting ability of loblolly pine stem cuttings were estimated with the individual binary observations by using REML estimation with the GAREML computer program (Huber 1993). However, upwardly biased estimates of genetic variances result when variance components are estimated from single-site (trial) analyses, since the estimated genetic variance also contains the genotype $\times$ environment interaction (Comstock and Moll 1963). Therefore, across-trial analyses were performed to separate the genotype $\times$ environment interactions to remove this bias:

$$
\begin{aligned}
y_{i j k l m n o}=\mu+T_{i}+R_{j(i)}+\operatorname{tray}_{k(j(i))}+\mathrm{gca}_{l}+\mathrm{gca}_{m}+\mathrm{sca}_{l m}+\operatorname{clone}(\mathrm{fam})_{n(l m)}+t & \times \mathrm{gca}_{i l}+t \times \mathrm{gca}_{i m}+t \times s c a_{i l m}+t \\
& \times \operatorname{clone}(\mathrm{fam})_{i n(l m)}+r \times \mathrm{fam}_{j(i) l m}+e_{i k j l m n o}
\end{aligned}
$$

where

$y_{i j k l m n o}$ is the rooting response (0 or 1$)$ of the $o$ th ramet of the $n$th clone within the $l m$ th full-sib family in the $k$ th tray within the $j$ th replication of the $i$ th trial

$\mu$ is the population mean

$T_{i}$ is the fixed effect of trial

$R_{j(i)}$ is the fixed effect of replication

$\operatorname{tray}_{k(j(i))}$ is the random variable tray (incomplete block) $\operatorname{IID}\left(0, \sigma_{\text {tray }}^{2}\right)$

gca $_{l}$ and gca $_{m}$ are the random variable female $(l)$ and male $(m)$ general combining ability (gca), respectively, $\sim \operatorname{IID}\left(0, \sigma_{\text {gca }}^{2}\right)$

$\mathrm{sca}_{l m}$ is the random variable specific combining ability $(\mathrm{sca}) \sim \operatorname{IID}\left(0, \sigma_{\mathrm{sca}}^{2}\right)$ clone (fam $)_{n(l m)}$ is the random variable clone within family $\sim \operatorname{IID}\left(0, \sigma_{\text {clone }}^{2}\right)$

$t \times \mathrm{gca}_{i l}$ and $t \times \mathrm{gca}_{i m}$ are the random variable test by female gca and test by male gca interaction, respectively, $\operatorname{IID}\left(0, \sigma_{\text {tgca }}^{2}\right)$

$t \times \mathrm{sca}_{i l m}$ is the random variable test by sca interaction $\sim$ $\operatorname{IID}\left(0, \sigma_{t \mathrm{sca}}^{2}\right)$

$t \times$ clone $(\text { fam })_{i n(l m)}$ is the random variable test by clone interaction $\sim \operatorname{IID}\left(0, \sigma_{\text {tclone }}^{2}\right)$

$r \times$ fam $_{j(i) l m}$ is the random variable replication by family interaction $\sim \operatorname{IID}\left(0, \sigma_{\text {rfam }}^{2}\right)$

$e_{i j k l m n o}$ is the random error, which includes among-plot and within-plot error $\sim \operatorname{IID}\left(0, \sigma_{e}^{2}\right)$ 
The single-trial model is identical, except all model factors with subscript $i$ are removed (sources involving test).

Genetic parameters were estimated and standard errors were calculated according to Foster and Shaw (1988) using the appropriate variance components from the individual or across-trial model. Estimates of additive and dominance genetic variance are upwardly biased because they are confounded with fractions of epistasis (Cockerham 1954). Epistastic genetic variance is also only approximated because it contains only a fraction of the total epistasis plus any $\mathrm{C}$ effects, if they exist:

$$
\hat{V}_{\mathrm{A}}=4 \hat{\sigma}_{\mathrm{gca}}^{2}=V_{\mathrm{A}}+\frac{1}{4} V_{\mathrm{AA}}+\frac{1}{16} V_{\mathrm{AAA}}+\ldots
$$

is the estimate of additive genetic variance.

$$
\hat{V}_{\mathrm{D}}=4 \hat{\sigma}_{\mathrm{sca}}^{2}=V_{\mathrm{D}}+\frac{1}{2} V_{\mathrm{AA}}+\frac{1}{2} V_{\mathrm{AD}}+\frac{1}{2} V_{\mathrm{DD}}+\ldots
$$

is the estimate of dominance genetic variance.

$$
\hat{V}_{\mathrm{I}}=\hat{\sigma}_{\mathrm{clone}}^{2}-2 \hat{\sigma}_{\mathrm{gca}}^{2}-3 \hat{\sigma}_{\mathrm{sca}}^{2}=\frac{1}{4} V_{\mathrm{AA}}+\frac{1}{2} V_{\mathrm{AD}}+\frac{3}{4} V_{\mathrm{DD}}+\ldots
$$

is the estimate of epistatic genetic variance.

$$
\text { [5] } \quad \hat{V}_{\mathrm{G}}=2 \hat{\sigma}_{\mathrm{gca}}^{2}+\hat{\sigma}_{\mathrm{sca}}^{2}+\hat{\sigma}_{\text {clone }}^{2}
$$

is the estimate of total genetic variance.

$$
\hat{V}_{\mathrm{P}}=2 \hat{\sigma}_{\mathrm{gca}}^{2}+\hat{\sigma}_{\mathrm{sca}}^{2}+\hat{\sigma}_{\mathrm{clone}}^{2}+2 \hat{\sigma}_{t \mathrm{gca}}^{2}+\hat{\sigma}_{t \mathrm{sca}}^{2}+\hat{\sigma}_{t \mathrm{clone}}^{2}+\hat{\sigma}_{r \mathrm{fam}}^{2}+\hat{\sigma}_{e}^{2}
$$

is phenotypic variance for the across-trial model (the phenotypic variance from the single-trial model is the same but without $2 \hat{\sigma}_{\text {tgca }}^{2}, \hat{\sigma}_{t \text { sca }}^{2}$, and $\left.\hat{\sigma}_{t \text { clone }}^{2}\right)$.

Biased and unbiased heritability estimates for rooting based on observed 0,1 data were derived using the estimated variance components from the single- and across-trial models, respectively. In addition the proportion of dominance $\left(\hat{d}^{2}\right)$ and epistasis $\left(\hat{i}^{2}\right)$ were estimated. Standard errors of these estimates were calculated using a Taylor series expansion (Kendall and Stuart 1963; Namkoong 1979; Huber et al. 1992; Dieters 1994).

$$
\hat{h}_{0,1}^{2}=\frac{4 \hat{\sigma}_{\mathrm{gca}}^{2}}{2 \hat{\sigma}_{\mathrm{gca}}^{2}+\hat{\sigma}_{\mathrm{sca}}^{2}+\hat{\sigma}_{\mathrm{clone}}^{2}+2 \hat{\sigma}_{\text {tgca }}^{2}+\hat{\sigma}_{t \mathrm{sca}}^{2}+\hat{\sigma}_{\text {tclone }}^{2}+\hat{\sigma}_{\mathrm{rfam}}^{2}+\hat{\sigma}_{e}^{2}}
$$

is the across-trial narrow-sense heritability based on observed binary data.

$$
\hat{H}_{0,1}^{2}=\frac{2 \hat{\sigma}_{\mathrm{gca}}^{2}+\hat{\sigma}_{\mathrm{sca}}^{2}+\hat{\sigma}_{\mathrm{clone}}^{2}}{2 \hat{\sigma}_{\mathrm{gca}}^{2}+\hat{\sigma}_{\mathrm{sca}}^{2}+\hat{\sigma}_{\mathrm{clone}}^{2}+2 \hat{\sigma}_{\text {tgca }}^{2}+\hat{\sigma}_{t \mathrm{sca}}^{2}+\hat{\sigma}_{\text {tclone }}^{2}+\hat{\sigma}_{r \mathrm{fam}}^{2}+\hat{\sigma}_{e}^{2}}
$$

is the across-trial broad-sense heritability based on observed binary data.

$$
\hat{d}_{0,1}^{2}=\frac{\hat{V}_{\mathrm{D}}}{\hat{V}_{\mathrm{P}}}=\frac{4 \hat{\sigma}_{\mathrm{sca}}^{2}}{2 \hat{\sigma}_{\mathrm{gca}}^{2}+\hat{\sigma}_{\mathrm{sca}}^{2}+\hat{\sigma}_{\text {clone }}^{2}+2 \hat{\sigma}_{t \mathrm{gca}}^{2}+\hat{\sigma}_{t \mathrm{sca}}^{2}+\hat{\sigma}_{t \mathrm{clone}}^{2}+\hat{\sigma}_{r \mathrm{fam}}^{2}+\hat{\sigma}_{e}^{2}}
$$

is the across-trial dominance proportion.

$$
\hat{i}_{0,1}^{2}=\frac{\hat{V}_{\mathrm{I}}}{\hat{V}_{\mathrm{P}}}=\frac{\hat{\sigma}_{\mathrm{clone}}^{2}-2 \hat{\sigma}_{\mathrm{gca}}^{2}-3 \hat{\sigma}_{\mathrm{sca}}^{2}}{2 \hat{\sigma}_{\mathrm{gca}}^{2}+\hat{\sigma}_{\mathrm{sca}}^{2}+\hat{\sigma}_{\mathrm{clone}}^{2}+2 \hat{\sigma}_{t \mathrm{gca}}^{2}+\hat{\sigma}_{t \mathrm{sca}}^{2}+\hat{\sigma}_{t \mathrm{clone}}^{2}+\hat{\sigma}_{r \mathrm{fam}}^{2}+\hat{\sigma}_{e}^{2}}
$$

is the across-trial epistatic proportion.

The main problem with calculating heritability on the observed 0,1 data is that the relationship between $h^{2}$ on the observed scale and $h^{2}$ on the underlying normal scale depends on the mean incidence (e.g., percent survival, percent infected individuals, rooting percentage), and therefore the conversion results in a biased estimate (Van Vleck 1971). However, this is not a problem for low-heritability traits with intermediate incidences (Lopes et al. 2000). To make valid comparisons with heritability estimates in other rooting trials that have different mean rooting percentages, $\hat{h}_{0,1}^{2}$ needs to be transformed to $h^{2}$ on the underlying normal scale. Therefore, narrow- and broad-sense heritability estimates on the observed 0,1 scale were transformed to an underlying normal scale using a threshold model (Dempster and Lerner 1950):

$$
\hat{h}_{\mathrm{N}}^{2}=\hat{h}_{0,1}^{2} \frac{p(1-p)}{z^{2}}
$$

where $\hat{h}_{\mathrm{N}}^{2}$ is the heritability on the underlying normal scale, $p$ is the rooting percentage, $z$ is the ordinate of the normal density function that corresponds to probability $p$. 
Full-sib family mean heritability and clonal mean heritability for rooting were estimated for both the single- and across-trial analyses. Standard errors for these estimates were calculated using Dickerson's method, which assumes the phenotypic variance (denominator) is a known constant (Dickerson 1969).

$$
\hat{h}_{\mathrm{fam}}^{2}=\frac{2 \hat{\sigma}_{\mathrm{gca}}^{2}+\hat{\sigma}_{\mathrm{sca}}^{2}}{2 \hat{\sigma}_{\mathrm{gca}}^{2}+\hat{\sigma}_{\mathrm{sca}}^{2}+\frac{\hat{\sigma}_{\mathrm{clone}}^{2}}{c}+\frac{2 \hat{\sigma}_{\text {tgca }}^{2}}{t}+\frac{\hat{\sigma}_{\text {tsca }}^{2}}{t}+\frac{\hat{\sigma}_{\text {tclone }}^{2}}{t c}+\frac{\hat{\sigma}_{\text {rfam }}^{2}}{t r}+\frac{\hat{\sigma}_{e}^{2}}{c t r n}}
$$

is the across-trial family mean heritability, where $c$ is the harmonic mean number of clones per family, $t$ is the number of trials, $r$ is the harmonic mean number of replications per test, and $n$ is the harmonic mean number of ramets per clone per plot.

$$
\hat{H}_{\text {clone }}^{2}=\frac{2 \hat{\sigma}_{\text {gca }}^{2}+\hat{\sigma}_{\text {sca }}^{2}+\hat{\sigma}_{\text {clone }}^{2}}{2 \hat{\sigma}_{\mathrm{gca}}^{2}+\hat{\sigma}_{\mathrm{sca}}^{2}+\hat{\sigma}_{\text {clone }}^{2}+\frac{2 \hat{\sigma}_{t \mathrm{gca}}^{2}}{t}+\frac{\hat{\sigma}_{\text {tsca }}^{2}}{t}+\frac{\hat{\sigma}_{t \mathrm{clone}}^{2}}{t}+\frac{\hat{\sigma}_{r \mathrm{fam}}^{2}}{t r}+\frac{\hat{\sigma}_{e}^{2}}{t r n}}
$$

is the across-trial clonal mean heritability.

Type B genetic correlations for rooting across all five trials were estimated for both additive and nonadditive components (Yamada 1962; Burdon 1977). Standard errors of type B correlations were calculated using the Taylor series expansion method.

$$
\hat{r}_{\mathrm{B}}=\frac{\hat{\sigma}_{\mathrm{g}}^{2}}{\hat{\sigma}_{\mathrm{g}}^{2}+\hat{\sigma}_{\mathrm{ge}}^{2}}
$$

where $\hat{r}_{\mathrm{B}}$ is the estimate of the type $\mathrm{B}$ genetic correlation, $\sigma_{\mathrm{g}}^{2}$ is the genetic variance component (either additive or dominance), and $\sigma_{\mathrm{ge}}^{2}$ is the genotype $\times$ environment interaction (additive and dominance).

\section{Results and discussion}

\section{Average rooting}

A total of over 239000 stem cuttings from nearly 2200 clones of loblolly pine were set in five rooting trials. Overall rooting across the five trials was $43 \%$ and is comparable to other rooting studies involving loblolly pine. Goldfarb et al. (1998) reported 44\% rooting of loblolly pine stem cuttings from 400 seedling hedges from one open-pollinated family. Over four rooting trials, Anderson et al. (1999) reported $33 \%$ rooting from 90 clones of loblolly pine from nine fullsib families. Foster (1990) reported overall rooting from three settings of $42 \%$ for 546 clones of loblolly pine derived from 54 full-sib families. However, studies with fewer families of loblolly pine have yielded substantially higher rooting percentages (Cooney and Goldfarb 1999; Murthy and Goldfarb 2001; LeBude et al. 2004).

Rooting of loblolly pine cuttings was variable over the five trials (Table 2). Spring cuttings rooted at greater than $50 \%$, while cuttings in the two summer trials averaged $38 \%$ and $24 \%$. Winter cuttings were intermediate at $45 \%$ rooting. Broad inference linear contrasts were constructed using the estimates of the fixed effects to test seasonal rooting responses. Cuttings set in the two spring trials rooted at a significantly greater frequency than cuttings set in the summer trials $(p<0.0001)$. This implies that we would always expect a greater rooting percentage in spring settings than in summer settings under this propagation system.
Seasonal rooting responses for loblolly pine stem cuttings have been observed in other studies. Early rooting trials of loblolly pine cuttings reported best rooting from cuttings set from September through January (Cech 1958; Reines and Bamping 1960; Grigsby 1962; Marino 1982). These early experiments concluded that increased temperatures in the greenhouse in spring and summer trials decreased rooting. In fact, Cech (1958) reported a threefold increase in rooting under cool conditions compared with rooting under warm conditions. However, Foster et al. (2000) observed an overall rooting of $50 \%$ for a rooting trial established in March, while only $20 \%$ rooting for a trial established in September. They hypothesized that the reduction in September rooting was due to a decrease in metabolic activity because of the decrease in photoperiod. Rowe et al. $(2002 a, 2002 b)$ reported trends in rooting similar to those of the current study. They observed 59\% rooting for spring cuttings versus $40 \%$ rooting for winter cuttings and $35 \%$ rooting for summer cuttings. Cooney and Goldfarb (1999) also reported high rooting percentages for spring cuttings $(62 \%$ and $83 \%$ in two successive years). In contrast, Murthy and Goldfarb (2001) reported higher rooting percentages for winter cuttings $(85 \%)$ than for spring cuttings $(60 \%)$. Winter cuttings often take longer to root, but overall rooting may not be different than that of spring cuttings. Perhaps the slight reduction in rooting frequency for the winter02 setting versus the two spring settings was a function of rate of rooting.

The reduction in rooting seen here for summer settings may be a result of increased temperatures during the collection and propagation phases of the experiment. The higher temperatures and humidity experienced during summer months may have resulted in an increased abundance or activity of pathogens, and hence a higher rate of decay was observed in the two summer trials. The time delay between collection and setting of cuttings may also have contributed to this reduction in rooting. Murthy and Goldfarb (2001) reported a decline in rooting percentage with increasing drying time of cuttings.

\section{Observed variance components}

Variance components were estimated for all single- and across-trial analyses (Baltunis 2005). Even with the reduction in the number of clones and families throughout the 
Table 2. Summary of rooting from five loblolly pine trials set over 2 years and three seasons.

\begin{tabular}{lllll}
\hline & $\begin{array}{l}\text { Rooting } \\
(\%)\end{array}$ & $\begin{array}{l}\text { Half-sib } \\
\text { family } \\
\text { range }(\%)\end{array}$ & $\begin{array}{l}\text { Full-sib } \\
\text { family } \\
\text { range }(\%)\end{array}$ & $\begin{array}{l}\text { Clone } \\
\text { range } \\
(\%)\end{array}$ \\
\hline Trial & 54 & $36-70$ & $28-77$ & $0-100$ \\
Suming01 & 38 & $24-54$ & $18-69$ & $0-100$ \\
Winter02 & 45 & $17-60$ & $17-67$ & $0-100$ \\
Spring02 & 51 & $36-67$ & $28-75$ & $0-98$ \\
Summer02 & 24 & $9-43$ & $8-53$ & $0-89$ \\
\hline
\end{tabular}

study, there was no apparent reduction in the variance component estimates over time as evidenced by parameter estimates, e.g., additive genetic variance estimates were relatively constant over time (Fig. 1). The variance associated with general combining ability was $2 \%$ of the total phenotypic variation associated with rooting. Half-sib family rooting percentages ranged from a high of $36 \%-70 \%$ for spring01 to a low of $9 \%-43 \%$ for summer02 (Table 2). The proportion of the total variation in rooting that was accounted for by specific combining ability was only $0.3 \%-1.1 \%$. Full-sib family means for rooting for the two spring settings ranged from $28 \%$ to $76 \%$. Although overall rooting was greater for these two spring trials, the net difference in the range of family means was approximately the same $(\sim 45 \%-51 \%)$. Similar ranges in family mean rooting percentages have been reported (Foster 1990; Anderson et al. 1999).

Clones within families accounted for approximately $10 \%-$ $17 \%$ of the total variation in rooting in the five trials (Baltunis 2005). Foster (1990) reported that the clone-within-family source of variation in rooting of 546 clones of loblolly pine was $3.7 \%$ of the total variation. However, in another study involving cuttings of loblolly pine, the among-clone source of variation accounted for nearly $22 \%$ of the total variation (Foster 1978). In the current study, the variance associated with clone within family was $4.5-8.4$ times as much as the gca variance and $13-56$ times as much as the sca variance based on single-trial analyses.

Just as there was a large range in rooting among families, there was also a large range in rooting among clones within families (Table 2). Rooting for clones within families ranged from $0 \%$ to $100 \%$ for the first three trials and from $0 \%$ to $98 \%$ and $0 \%$ to $89 \%$ in the last two trials. Anderson et al. (1999) observed ranges in rooting frequency for clones within family similar to those observed in this study. Foster (1990) reported significant variation for clones within family with rooting percentages ranging from $6.7 \%$ to $85.0 \%$.

A large variation in the rooting environment has been reported in many rooting experiments of loblolly pine and other species, with an error variance ranging from $46 \%$ to $71 \%$ (Foster 1978, 1990; Sorensen and Campbell 1980; Cunningham 1986). In the current study, most of the observed variance in rooting was attributable to the error variance. The error variance accounted for $76.3 \%-83.7 \%$ of the total variance observed in the five trials. Each rooting trial was spread over an entire greenhouse because of the large size of the experiments. Apparently, the rooting environment was not uniform throughout the greenhouse. There are many factors that can contribute to a variable rooting environment, namely differ- ential temperature gradients, unequal airflow, unequal misting of cuttings, edge effects, and disease incidence.

\section{Causal variance components}

The observed variance components were used to estimate additive, dominance, and epistatic variances using eqs. 2, 3 and 4 , respectively. Additive genetic variance was approximately four to six times larger than the dominance genetic variation for rooting in the five trials (Fig. 1). In Foster (1990), the additive genetic variance was also about six times larger than the dominance genetic variance. However, Anderson et al. (1999) found three times and Foster (1978) found 2.2 times greater dominance genetic variance in rooting compared with the additive variance in loblolly pine stem cuttings. The epistatic genetic variance was also estimated in the current study and was approximately 0.44 to 1.49 times as much as the additive genetic variance. The lowest amount of epistasis was observed for the winter setting, which was the only setting that had a nonadditive/additive ratio less than one.

C effects can lead to upwardly biased estimates of total genetic and nonadditive genetic components of variance when analyzing clonal data (Libby and Jund 1962). If C effects are present, then total genetic variation associated with clones will be overestimated (Libby and Jund 1962). Significant C effects are likely to occur in traits that are measured soon after propagation (such as rooting traits, early shoot growth, etc.), but apparently lessen for traits measured at later times (Libby and Jund 1962). Foster et al. (1984) used a secondary cloning approach to separate $\mathrm{C}$ effects from the genetic variance in rooting of western hemlock (Tsuga heterophylla (Raf.) Sarg.) cuttings. They found significant $\mathrm{C}$ effects associated with rooting and that these nongenetic effects biased the genotypic values of clones. However, low or nonsignificant $\mathrm{C}$ effects for rooting of tamarack (Larix laricina (Du Roi) K. Koch) and balsam poplar (Populus balsamifera L.) cuttings have been reported (Farmer et al. 1989, 1992). In the current study, estimates of epistatic genetic variance components are confounded with $\mathrm{C}$ effects, because ramets of a clone came from the original seedling ortet. However, estimates of additive and dominance genetic effects are not confounded with $\mathrm{C}$ effects, because the clones within families were randomized in the hedge orchard.

\section{Heritability estimates}

Rooting of loblolly pine stem cuttings was weakly controlled by additive effects. Individual-tree narrow-sense heritability using the observed variance components $\left(\hat{h}_{0,1}^{2}\right)$ ranged from 0.075 to 0.089 in the five separate trials (Fig. 1). These estimates are in agreement with those of Foster (1978), who reported $\hat{h}^{2}$ as 0.07 for rooting percentage of loblolly pine. A slightly higher $\hat{h}^{2}$ was reported by Foster (1990). However, Anderson et al. (1999) reported $\hat{h}^{2}$ of 0.26 for rooting percentage in loblolly pine stem cuttings. However, all of these previous studies of loblolly pine rooted cuttings analyzed data based on plot rooting percentage, as opposed to using 0,1 data as in this study, and this leads to an increased estimate of heritability because of the reduction of the impact of the within-plot portion of the error variance in any plot means or plot percentage analysis for rooting. When the data in the current study were analyzed based on rooting 
Fig. 1. The proportion of the additive $\left(\hat{h}_{0,1}^{2}\right)$, dominance $\left(\hat{d}_{0,1}^{2}\right)$, and epistasis $\left(\hat{i}_{0,1}^{2}\right)$ genetic variances on the observed binary scale for rooting of loblolly pine stem cuttings from each of the five separate trials (biased heritabilities) and from the combined analysis of all five trials. Standard error bars for broad-sense heritability estimates are shown.

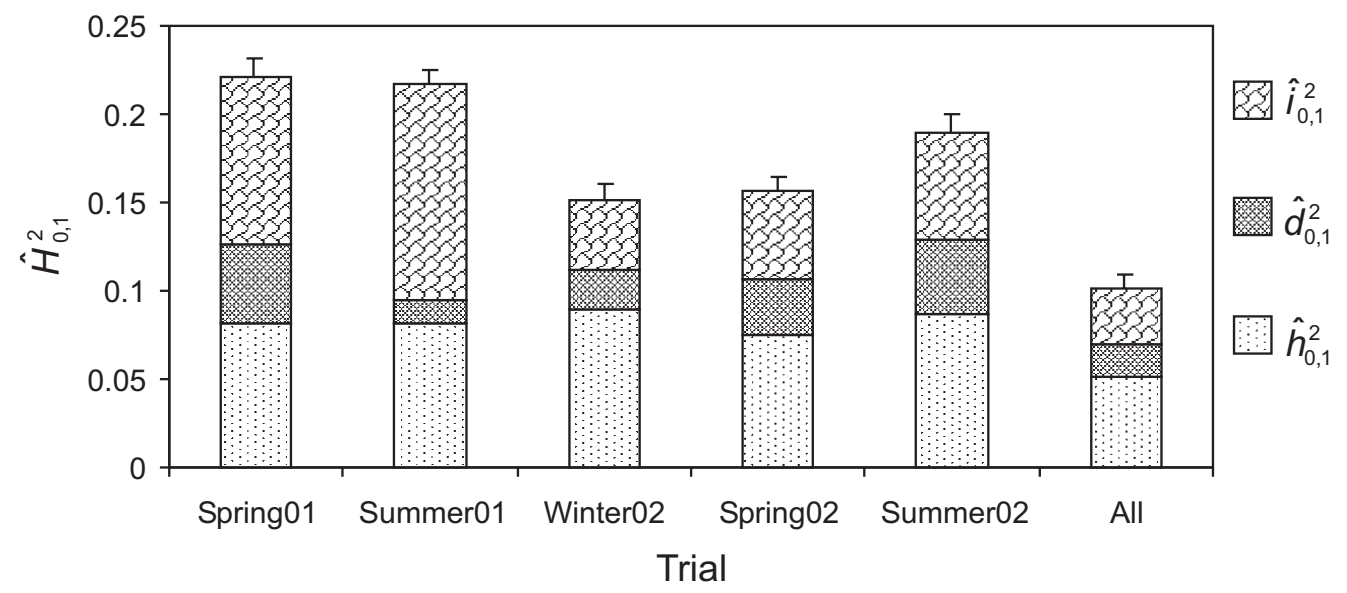

Table 3. Genetic parameter estimates for rooting of loblolly pine stem cuttings across five trials.

\begin{tabular}{ll}
\hline Parameter & Estimate \\
\hline Narrow-sense heritability on observed binary scale $\left(\hat{h}_{0,1}^{2}\right)$ & $0.051(0.017)$ \\
Broad-sense heritability on observed binary scale $\left(\hat{H}_{0,1}^{2}\right)$ & $0.101(0.008)$ \\
Narrow-sense heritability on the underlying normal scale $\left(\hat{h}_{\mathrm{N}}^{2}\right)$ & $0.08(0.027)$ \\
Broad-sense heritability on the underlying normal scale $\left(\hat{H}_{\mathrm{N}}^{2}\right)$ & $0.16(0.013)$ \\
Narrow-sense family mean heritability $\left(\hat{h}_{\text {fam }}^{2}\right)$ & $0.833(0.24)$ \\
Broad-sense clonal mean heritability $\left(\hat{H}_{\text {clone }}^{2}\right)$ & $0.815(0.074)$ \\
Additive genetic variance $\left(\hat{V}_{\mathrm{A}}\right)$ & $0.0117(0.004)$ \\
Dominance genetic variance $\left(\hat{V}_{\mathrm{D}}\right)$ & $0.0042(0.002)$ \\
Epistatic genetic variance $\left(\hat{V}_{\mathrm{I}}\right)$ & $0.0074(0.002)$ \\
Phenotypic variance $\left(\hat{V}_{\mathrm{P}}\right)$ & $0.2297(0.002)$ \\
Type B additive genetic variance correlation & $0.68(0.23)$ \\
Type B dominance genetic variance correlation & $0.61(0.27)$ \\
Type B total genetic variance correlation & $0.53(0.048)$ \\
\hline
\end{tabular}

Note: Standard errors are given in parentheses.

percentage, $\hat{h}^{2}$ was 0.18 (from spring01, data not shown), which falls in the middle of the range previously reported.

The unbiased estimates of individual-tree narrow-sense heritability $\left(\hat{h}_{0,1}^{2}\right)$ using the 0,1 data from the pairwise test analyses ranged from 0.045 to 0.074 . When all of the data from the five trials were analyzed together, $\hat{h}_{0,1}^{2}$ was 0.051 (Table 3; Fig. 1). The proportion of dominance $\left(\hat{d}_{0,1}^{2}\right)$ was estimated for each of the trials. The upwardly biased estimates for this parameter ranged from 0.014 to 0.044 (Fig. 1). When all of the data were analyzed together from the five trials, $\hat{d}^{2}$ was 0.018 (Table 3; Fig. 1). The epistatic proportion $\left(i_{0,1}^{2}\right)$ was also estimated and ranged from 0.032 to 0.095 (Table 3; Fig. 1).

Broad-sense heritability $\left(\hat{H}_{0,1}^{2}\right)$ ranged from approximately 0.15 to 0.22 (Fig. 1). Broad-sense heritability was 0.101 when all of the data from the five trials were combined (Table 3; Fig. 1). Foster (1990) observed very little nonadditive genetic variance and reported $\hat{H}^{2}$ of 0.13 for rooting percentage. In another study, $\hat{H}^{2}$ was reported as 0.23 for rooting percentage (Foster 1978). However, Anderson et al. (1999) reported a much higher $\hat{H}^{2}(0.63)$ for rooting percentage of loblolly pine. When the data in this study were analyzed based on rooting percentage, $\hat{H}^{2}$ was 0.47 .

Narrow- and broad-sense heritability estimates on the observed 0,1 scale were transformed to an underlying normal scale assuming a threshold model (eq. 16). Narrow-sense heritability based on the underlying normal scale $\left(\hat{h}_{\mathrm{N}}^{2}\right)$ ranged from 0.12 to 0.16 (Fig. 2). Broad-sense heritability based on the underlying normal scale $\left(\hat{H}_{\mathrm{N}}^{2}\right)$ ranged from 0.24 to 0.36 (Fig. 2). When all of the data from the five settings were analyzed together, then $\hat{h}_{\mathrm{N}}^{2}$ was 0.08 and $\hat{H}_{\mathrm{N}}^{2}$ was 0.16 (Table 3 ; Fig. 2). The transformation of $\hat{h}_{0,1}^{2}$ and $\hat{H}_{0,1}^{2}$ to the underlying normal scale allows direct comparisons of heritability estimates among rooting studies when the rooting percentages are different.

Family mean heritability ranged from 0.84 to 0.9 , while clonal mean heritability ranged from 0.82 to 0.92 (Fig. 3). When all of the data from the five trials were combined, $\hat{h}_{\mathrm{fam}}^{2}$ was 0.83 and $\hat{H}_{\text {clone }}^{2}$ was 0.82 (Table 3; Fig. 3). For a rooting 
Fig. 2. Narrow-sense $\left(\hat{h}_{\mathrm{N}}^{2}\right)$ and broad-sense $\left(\hat{H}_{\mathrm{N}}^{2}\right)$ heritability estimates for rooting of loblolly pine stem cuttings transformed to the underlying normal scale using the threshold model of eq. 16. Standard error bars are shown.

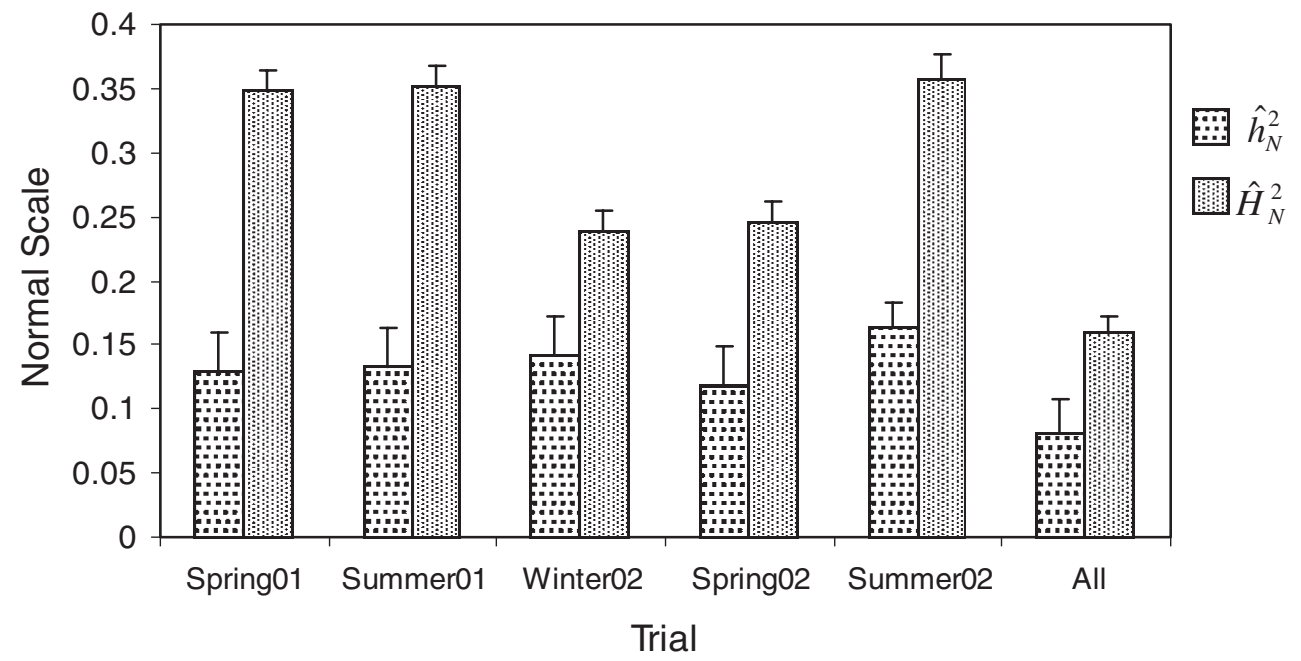

Fig. 3. Narrow-sense family mean $\left(\hat{h}_{\text {fam }}^{2}\right)$ and broad-sense clonal mean $\left(\hat{H}_{\text {clone }}^{2}\right)$ heritability estimates for rooting success of 2200 clones from 70 full-sib families of loblolly pine. Standard error bars are shown.

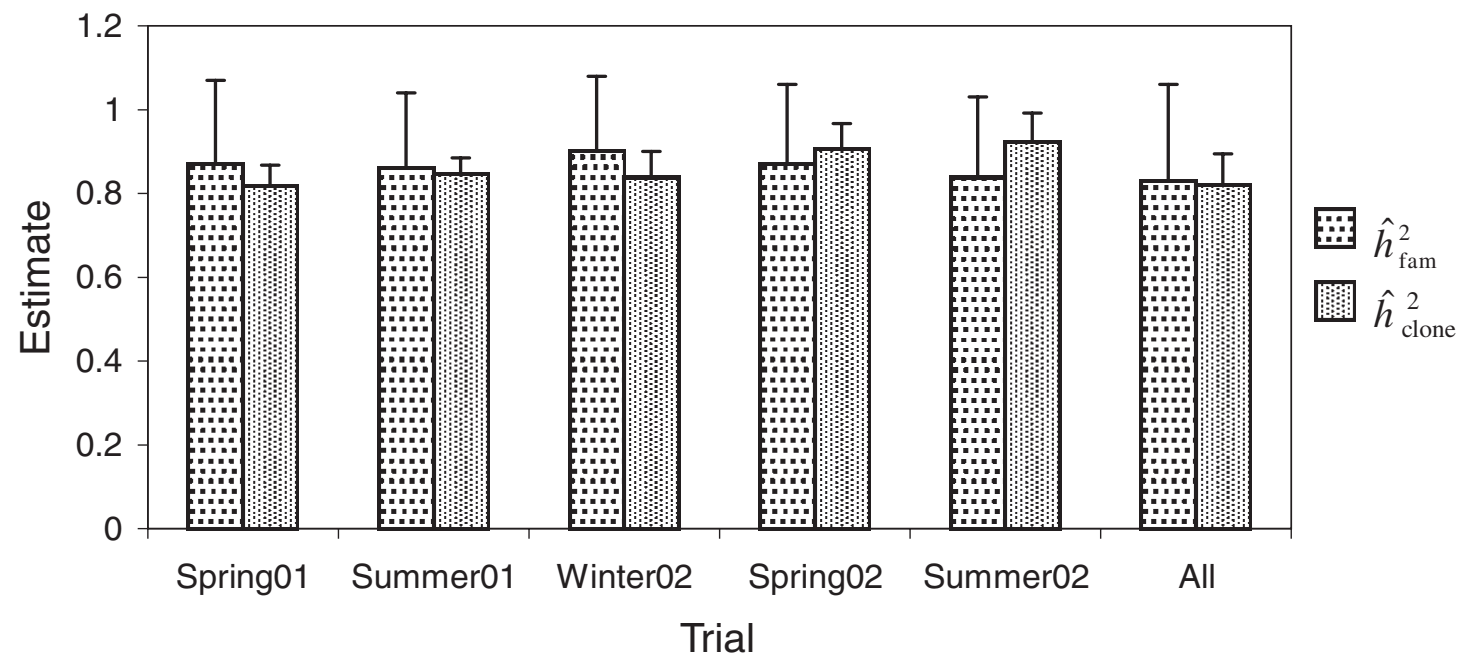

study consisting of 540 clones of loblolly pine from 54 fullsib families, Foster (1990) reported lower estimates of both family mean heritability and clonal mean heritability, 0.46 and 0.40 , respectively. In another loblolly pine rooting study with 27 full-sib families consisting of 10 clones each, family mean heritability was reported as 0.31 , while the clonalmean heritability was 0.87 (Anderson et al. 1999).

\section{Type B genetic correlations}

The type $\mathrm{B}$ correlations for additive effects were moderately high and ranged from 0.53 to 0.91 (Table 4), indicating that parental rankings of the 32 parents were moderately to strongly correlated among pairs of trials. When all of the data were analyzed together from the five trials, the type B additive correlation was 0.68 . The highest type $\mathrm{B}$ correlation was observed between the two spring settings, which were 1 year apart, while the lowest correlations were observed between the winter setting (winter02) and other trials. Spring and summer cuttings were, in general, actively growing, succulent material, while winter cuttings were generally smaller and more lignified. Perhaps, some of the genes controlling rooting of dormant winter cuttings are different than those controlling spring and summer cuttings.

Type B correlations for dominance effects, which measure the correspondence of dominance across pairs of trials, were estimated to be moderate to high (Table 4), with two exceptions. First, the type B dominance correlation between trials 1 and 3 was 0.192. Also, dominance genetic variance was not detected in the pairwise analysis of trials 3 and 5. However, when all of the data were analyzed together, the type B dominance correlation was 0.61 .

\section{Selection for rooting}

Before clones of loblolly pine can be deployed operationally, two things must occur. First, the clones have to be field tested and selected for desirable traits, e.g., growth, disease resistance, and wood properties. Second, the selected clones have to be propagated in large enough numbers for deployment. For a rooted cutting-based program, this involves bulking up the number of hedges of a particu- 
Table 4. Type B additive and dominance variance correlations among pairs of rooting trials for loblolly pine stem cuttings (above and below diagonal, respectively).

\begin{tabular}{llllll}
\hline & Spring01 & Summer01 & Winter02 & Spring02 & Summer02 \\
\hline Spring01 & & $0.701(0.11)$ & $0.59(0.15)$ & $0.911(0.07)$ & $0.851(0.08)$ \\
Summer01 & $0.823(0.19)$ & & $0.634(0.12)$ & $0.673(0.12)$ & $0.634(0.13)$ \\
Winter02 & $0.192(0.30)$ & $0.629(0.34)$ & & $0.656(0.12)$ & $0.525(0.16)$ \\
Spring02 & $0.493(0.24)$ & $0.533(0.35)$ & $0.724(0.24)$ & & $0.907(0.06)$ \\
Summer02 & $0.777(0.22)$ & $0.973(0.37)$ & 0.000 & $0.703(0.24)$ & \\
\hline
\end{tabular}

Note: Standard errors are given in parentheses.

lar clone or group of clones through serial propagation and then producing reforestation stock efficiently from the bulked-up clones. Only those clones that can be propagated easily will be economically feasible for deployment. Therefore, selection of clones for rootability as well as field performance should be considered as part of a clonal forestry program based on rooted cutting technology (Foster et al. $1985,2000)$. In the current study, selection of the top $10 \%$ of clones for rooting ( 220 clones) would result in a gain of about $24 \%$ in rooting, with the gain estimated as (Foster 1990)

$$
\text { Gain }=i_{\text {clone }} \hat{H}_{\text {clone }}^{2} \sqrt{2 \hat{\sigma}_{\text {gca }}^{2}+\hat{\sigma}_{\text {sca }}^{2}+\hat{\sigma}_{\text {clone }}^{2}+\frac{2 \hat{\sigma}_{t \mathrm{gca}}^{2}}{t}+\frac{\hat{\sigma}_{t \mathrm{sca}}^{2}}{t}+\frac{\hat{\sigma}_{\text {tclone }}^{2}}{t}+\frac{\hat{\sigma}_{r \mathrm{fam}}^{2}}{t r}+\frac{\hat{\sigma}_{e}^{2}}{t r n}}
$$

where $i_{\text {clone }}$ is the standardized selection intensity for clones. Selecting the top $1 \%$ of clones for rooting would result in a gain of nearly $37 \%$ in rooting of loblolly pine stem cuttings in the current generation. Alternatively, genetic gain in rooting success in the next generation can be achieved through selection and breeding:

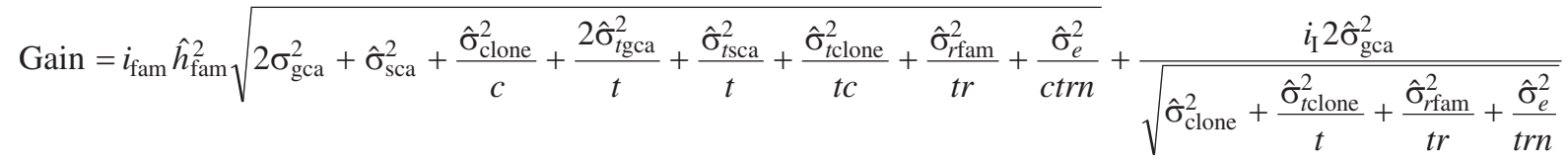

where $i_{\text {fam }}$ is the standardized selection intensity for full-sib families, and $i_{\mathrm{I}}$ is the standardized selection intensity for clones within full-sib families. By selecting the best rooting clone from the top 25 of 70 families, gain in rooting success of $16.8 \%$ can be expected in the next generation by breeding these 25 selections.

\section{Conclusion}

Loblolly pine is the most important commercial tree species in the southeastern United States. Several forest industry companies are developing rooted cutting programs for loblolly pine to maximize genetic gains through deployment of tested clones. With rooting data from 2200 clones from 70 full-sib families, the current study gives better estimates of genetic components of variance for rooting than several previous studies. These results show a great deal of genetic variation for rooting among families and clones of loblolly pine. Only those clones that can be propagated easily will be economically feasible for deployment. Therefore, selection of clones for rooting ability as well as field performance should be considered as part of a clonal forestry program based on rooted cutting technology. Combined with moderate to high estimates of family and clonal mean heritabilities and type B correlations, these results indicate the potential for increasing rooting efficiency by selecting good rooting families and clones or culling poor rooters.

\section{Acknowledgements}

The authors thank the members of the Forest Biology Research Cooperative for supporting this research. Also, thanks to International Paper Company for providing the greenhouses and assistance for all the propagation. This research was supported and approved for publication by the Florida Agricultural Experiment Station.

\section{References}

Anderson, A.B., Frampton, L.J., and Weir, R.J. 1999. Shoot production and rooting ability of cuttings from juvenile greenhouse loblolly pine hedges. Trans. Ill. State Acad. Sci. 92(1 and 2): 1-14.

Baltunis, B.S. 2005. Estimating genetic parameters associated with loblolly pine (Pinus taeda L.) clones. Ph.D. dissertation, University of Florida, Gainesville, Fla.

Banks, B.D., Mao, I.L., and Walter, J.P. 1985. Robustness of the restricted maximum likelihood estimator derived under normality as applied to data with skewed distributions. J. Dairy Sci. 68: 1785-1792.

Burdon, R.D. 1977. Genetic correlation as a concept for studying genotype-environment interaction in forest tree breeding. Silvae Genet. 26: $168-175$.

Cech, F.C. 1958. The vegetative propagation of Pinus taeda L. (loblolly pine). Ph.D. dissertation, Texas A. \& M., College Station, Tex.

Cockerham, C.C. 1954. An extension of the concept of partitioning hereditary variance for analysis of covariance among relatives when epistasis is present. Genetics, 39: 859-882.

Comstock, R.E., and Moll, R.H. 1963. Genotype-environment interactions. In Statistical genetics and plant breeding. Edited by 
R.E. Hanson and H.F. Robinson. NAS-NRC Publ. 982. pp. 5393.

Cooney, G., and Goldfarb, B. 1999. Effects of shearing height, pruning intensity, shoot origin and family on shoot morphology and their effects on rooting of loblolly pine stem cuttings. In Proceedings of the 25th Biennial Southern Forest Tree Improvement Conference, 11-14 July 1999, New Orleans, La. pp. 5253.

Cunningham, M.W. 1986. Genetic variation in rooting ability of American sycamore cuttings. In Proceedings of Research and Development Conference, September 1986, Atlanta, Ga. Technical Association of the Pulp and Paper Industry, Norcross, Ga. pp. 1-6.

Dempster, E.R., and Lerner, I.M. 1950. Heritability of threshold characters. Genetics, 35: 212-236.

De Souza, S.M., White, T.L., Hodge, G.R., and Schmidt, R.A. 1991. Genetic parameter estimates for greenhouse traits of slash pine artificially inoculated with fusiform rust fungus. For. Sci. 37: $836-848$.

Dickerson, G.E. 1969. Techniques for research in quantitative animal genetics In Techniques and procedures in animal science research. American Society of Animal Science, Albany, N.Y. pp. 36-79.

Dieters, M.J. 1994. Inheritance of volume and rust resistance in slash pine. Ph.D. dissertation, University of Florida, Gainesville, Fla.

Dieters, M.J., Hodge, G.R., and White, T.L. 1996. Genetic parameter estimates for resistance to rust (Cronaritum quercuum) infection from full-sib tests of slash pine (Pinus elliottii), modelled as functions of rust incidence. Silvae Genet. 45: 235-242.

Farmer, R.E., Durst, J.T., Deng Shaotang, and Yang Jun-tao. 1992. Effects of clones, primary ramets, and age of stock plants on tamarack rooting. Silvae Genet. 41: 22-24.

Farmer, R.E., Freitag, M., and Garlick, K. 1989. Genetic variance and "C" effects in balsampoplar rooting. Silvae Genet. 38: 62-65.

FBRC. 2000. Study B: clonal biology and performance of elite genotypes of loblolly and slash pine. Forest Biology Research Cooperative, University of Florida, Gainesville, Fla. FBRC Rep. 13

Foster, G.S. 1978. Genetic variation in rooting stem cuttings from four year old loblolly pine. Weyerhaeuser Co., Hot Springs, Ariz. Tech. Rep. 042-3204/78/97.

Foster, G.S. 1990. Genetic control of rooting ability of stem cuttings from loblolly pine. Can. J. For. Res. 20: 1361-1368.

Foster, G.S., and Shaw, D.V. 1988. Using clonal replicates to explore genetic variation in a perennial plant species. Theor. Appl. Genet. 76: 788-794.

Foster, G.S., Campbell, R.K., and Adams, W.T. 1984. Heritability, gain, and $\mathrm{C}$ effects in rooting of western hemlock cuttings. Can. J. For. Res. 14: 628-638.

Foster, G.S., Campbell, R.K., and Adams, W.T. 1985. Clonal selection prospects in western hemlock combining rooting traits with juvenile height growth. Can. J. For. Res. 15: 488-493.

Foster, G.S., Stelzer, H.E., and McRae, J.B. 2000. Loblolly pine cutting morphological traits: effects on rooting and field performance. New For. 19: 291-306.

Frampton, L.J., Goldfarb, B., and Surles, S.E. 1999. Nursery rooting and growth of loblolly pine cuttings: effects of rooting solution and full-sib family. South. J. Appl. For. 23(2): 108-116.

Goldfarb, B., Surles, S.E., Thetford, M., and Blazich, F.A. 1998. Effects of root morphology on nursery and first-year field growth of rooted cuttings of loblolly pine. South. J. Appl. For. 22(4): 231-234.

Greenwood, M.S., and Weir, R.J. 1995. Genetic variation in rooting ability of loblolly pine cuttings: effects of auxin and family on rooting by hypocotyl cuttings. Tree Physiol. 15: 41-45.
Grigsby, H.C. 1962. Propagation of loblolly pine by cuttings. Comb. Proc. Int. Plant Propag. Soc. 11: 33-35.

Huber, D.A. 1993. Optimal mating designs and optimal techniques for analysis of quantitative traits in forest genetics. Ph.D. dissertation, Forest Resources Conservation, University of Florida, Gainesville, Fla.

Huber, D.A., White, T.L., and Hodge, G.R. 1992. The efficiency of half-sib, half-diallel and circular mating designs in the estimation of genetic parameters in forestry: a simulation. For. Sci. 38(4): 757-776.

Huber, D.A., White, T.L., and Hodge, G.R. 1994. Variance component estimation techniques compared for two mating designs with forest genetic architecture through computer simulation. Theor. Appl. Genet. 88: 236-242.

Isik, F., Li, B., and Frampton, L.J. 2003. Additive, dominance, and epistatic variance estimates from a replicated clonal test of loblolly pine. For. Sci. 49: 77-88.

Isik, F., Li, B., Frampton, J., and Goldfarb, B. 2004. Efficiency of seedlings and rooted cuttings for testing and selection in Pinus taeda. For. Sci. 50: 44-53.

Kendall, M.G., and Stuart, A. 1963. The advanced theory of statistics. Vol. 1. Hafner, New York.

LeBude, A.V., Goldfarb, B., Blazich, F.A., Wise, F.C., and Frampton, L.J., Jr. 2004. Mist, medium water potential, and cutting water potential influence rooting of stem cuttings of loblolly pine. Tree Physiol. 24: 823-831.

Libby, W.J., and Jund, E. 1962. Variance associated with cloning. Heredity, 17: 533-540.

Lopes, U.V., Huber, D.A., and White, T.L. 2000. Comparison of methods for prediction of genetic gain from mass selection on binary threshold traits. Silvae Genet. 49: 50-56.

Lush, J.L., Lamoreux, W.F., and Hazel, L.N. 1948. The heritability of resistance to death in the fowl. Poult. Sci. 27(4): 375-388.

Marino, T.M. 1982. Propagation of southern pines by cuttings. Comb. Proc. Int. Plant Propag. Soc. 31: 518-524.

McKeand, S., Mullin, T., Byram, T., and White, T. 2003. Deployment of genetically improved loblolly and slash pines in the south. J. For. 101(3): 32-37.

Murthy, R., and Goldfarb, B. 2001. Effect of handling and water stress on water status and rooting of loblolly pine stem cuttings. New For. 21: 217-230.

Namkoong, G. 1979. Introduction to quantitative genetics in forestry. USDA For. Serv. Tech. Bull. 1588.

Reines, M., and Bamping, J.H. 1960. Seasonal rooting responses of slash and loblolly pine cuttings. J. For. 58: 646-647.

Rockwood, D.L., and Goddard, R.E. 1973. Predicted gains for fusiform rust resistance in slash pine. In Proceedings of the 12th Southern Forest Tree Improvement Conference, 12-13 June 1973, Baton Rouge, La. pp. 31-37.

Roff, D.A. 1997. Evolutionary quantitative genetics. Chapman and Hall, New York.

Rowe, D.B., Blazich, F.A., and Raper, C.D. 2002a. Nitrogen nutrition of hedged stock plants of loblolly pine. I. Tissue nitrogen concentrations and carbohydrate status. New For. 24: 39-51.

Rowe, D.B., Blazich, F.A., Goldfarb, B., and Wise, F.C. 2002b. Nitrogen nutrition of hedged stock plants of loblolly pine. II. Influence of carbohydrate and nitrogen status on adventitious rooting of stem cuttings. New For. 24: 53-65.

Sohn, S.I., and Goddard, R.E. 1979. Influence of infection percent on improvement of fusiform rust resistance in slash pine. Silvae Genet. 28: 173-180.

Sorensen, F.C., and Campbell, R.K. 1980. Genetic variation in rootability of cuttings from one-year-old western hemlock seedlings. USDA For. Serv. Res. Note PNW-352. 
Van Vleck, L.D. 1972. Estimation of heritability of threshold characters. J. Dairy Sci. 55: 218-225.

Weber, J., and Stelzer, H. 2002. Operational rooted cuttings in southern pines. In National Proceedings: Forest and Conservation Nursery Associations - 1999, 2000, and 2001. Technical coordinators R.K. Dumroese, L.E. Riley, and T.D. Landis. Proceedings RMRS-P-24. USDA Forest Service, Rocky Mountain Research Station, Ogden, Utah. pp. 91-92.
Westfall, P.H. 1987. A comparison of variance component estimates for arbitrary underlying distributions. J. Amer. Stat. Assoc. 82(399): 866-874.

Yamada, Y. 1962. Genotype by environment interaction and genetic correlation of the same trait under different environments. Jap. J. Genet. 37: 498-509. 